\title{
RESTAUREREN: EEN KLEIN GEVECHT TEGEN DE TIJD De restauratie van twee Balinese schilderingen
}

In september 2008 schonk de Vereniging van Vrienden van Instituut Kern twee Balinese schilderingen aan Museum Volkenkunde in Leiden. Deze doeken waren gemaakt voor het crematieritueel van de vorst van Karangasem, I Gusti Gde Djelantik, in $1916 .{ }^{1}$ Voorwaarde voor de schenking was dat ze zouden worden gerestaureerd. Hiertoe benaderde het museum Tempus Fugit, een maatschap voor restauratie van etnografica. ${ }^{2}$ Afgelopen april organiseerde Museum Volkenkunde een feestelijke bijeenkomst voor de leden van de Vereniging van Vrienden van Instituut Kern als dank voor de schenking. Tijdens deze bijeenkomst is door de auteur een presentatie gegeven over restauratie in het algemeen naar aanleiding van de behandeling van de doeken. Dit artikel is gebaseerd op die presentatie.

\section{Het materiaal}

Het katoen is industrieel vervaardigd, mogelijk in Twente. De verf voor deze doeken is op Bali op traditionele wijze gemaakt. Het blauw is indigo, rood is het klassieke Chinese rood (kencu), oker is afkomstig van stenen die als ballast door de Chinezen werden meegenomen en in de haven gelost als ze niet meer nodig waren, waarna de Balinezen ze opvisten om ze fijn te wrijven. Wit werd vervaardigd uit verbrande varkensschedels en zwart werd gemaakt van lampenroet. ${ }^{3}$ Het bladgoud is ook op Bali gemaakt en met dierlijke lijm vastgezet.

\section{Restauratie}

Restaureren wil niet altijd zeggen dat de beeltenis teruggebracht wordt tot de oorspronkelijke staat. In dit geval was het doel de doeken te consolideren en wat nog aanwezig was visueel te verbeteren. Om te refereren aan de uitspraak 'Parels in een baaierd van lacunes' die Pauline Lunsingh Scheurleer deed in een acquisitienota: de doeken zitten vol lacunes, soms letterlijk in de vorm van parels. De restauratieopdracht aan Tempus Fugit was niet deze leemten in te vullen.

Hoewel het lastig lijkt verschillen te constateren tussen 'restauratie in het algemeen' en 'etnografica restaureren' kent het laatste twee duidelijke kenmerken. Ten eerste worden gebruikssporen niet uitgewist omdat die informatie bevatten over hoe het object gebruikt werd. Ten tweede bestaan veel etnografische objecten uit verschillende materialen, waardoor een brede (vooral organische) materialenkennis is vereist.

Iedere restauratie begint uiteraard met scherpe observatie van het object. Het grootste doek, RMV 6090-2 (afb. 1), met de voorstelling uit het Mahabaratha over het verkrijgen van het onsterfelijkheidselixer, had vreemde vlekken, die rondom gespat zijn, ook omhoog. Aangezien de oorzaak hiervan niet 


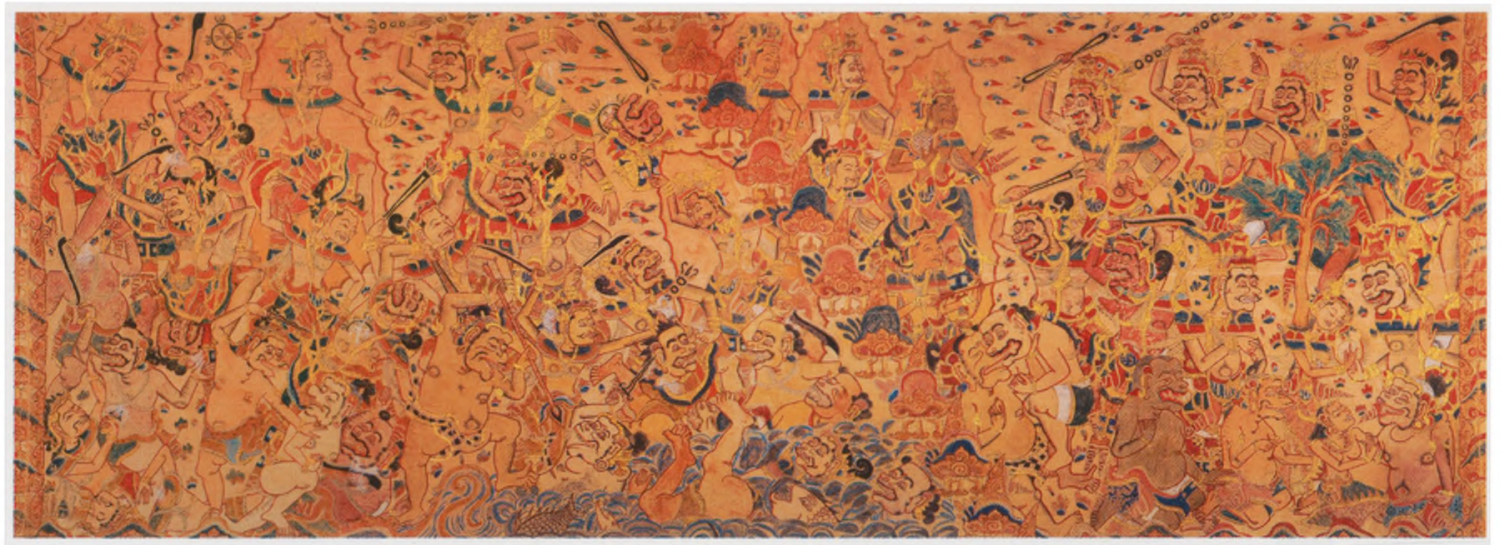

Afbeelding 1

Schildering op doek, Strijd tussen de goden en demonen om de amrta, h. 166 cm., I. 455 cm., Bali, inv.nr. RMV 6oga-2. Foto: Ben Grishaaver
Afbeelding 2

Scheur voor de behandeling. Detail RMV 6ogo-2. Foto: Regien Geerke

Afbeelding 3

Scheur na de behandeling. Detail RMV 60902. Foto: Regien Geerke
Het kleinste doek, RMV 6090-1, met een voorstelling uit het Ramayana, had een vreemde witte uitbloei. Uit onderzoek door het laboratorium van Instituut Collectie Nederland bleek dat dit magnesiumsulfaat betrof. Dit komt onder andere voor in badzepen. Misschien is het doek gewassen vóór de beschildering en zijn restanten van niet goed uitgespoelde zeep in de loop van de tijd uitgekristalliseerd. $\mathrm{Al}$ is dit niet met zekerheid te stellen, wel is bekend dat deze zeep in de textielindustrie gebruikt wordt. De uitgebloeide kristallen moeten mechanisch worden verwijderd, omdat ze deels als los wit stof, deels als niet bedoeld en dus afleidend wit op het doek zitten en visueel storen.

In het kort verliep het uiteindelijke restauratiewerk van beide doeken als volgt: om de behandeling mogelijk te maken werden allereerst hulpsteunen gemaakt om de spaties tussen de latten van het frame op te vullen. Zo konden de doeken vlak liggen en kon de behandeling beginnen.

Daarna werden stof en vuil van vele jaren verwijderd. Daardoor zijn de kleuren helderder geworden. Tegelijk werd de uitbloei voor zover mogelijk aangepakt zonder de verf te beschadigen. Het was niet mogelijk de uitbloei geheel te verwijderen, omdat deze vanuit de vezel van het doek door de verf heen groeide.

Iedere kleur moet worden getest omdat hij verschillend kan reageren op de diverse oplosmiddelen. Op grond van de uitkomst wordt het consolideringsproces bepaald.
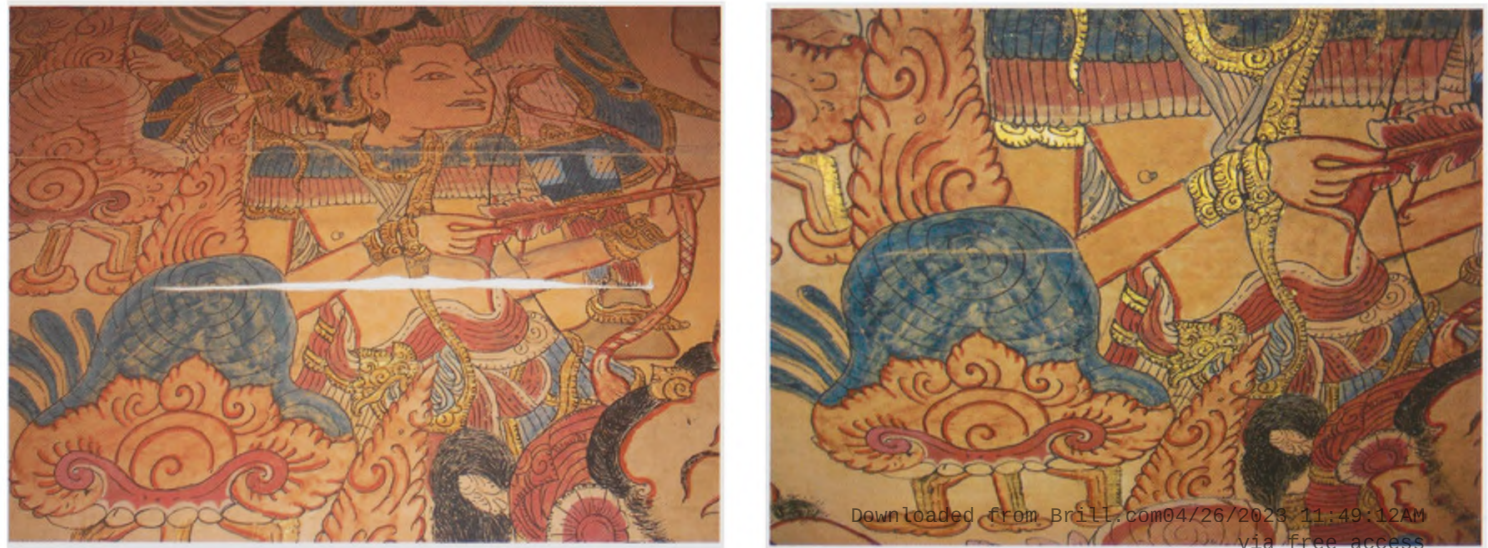
Afbeelding 4

Verkleuringen zichtbaar na verwijderen van de deklat. Detail RMV 6090-1. Foto: Regien Geerke

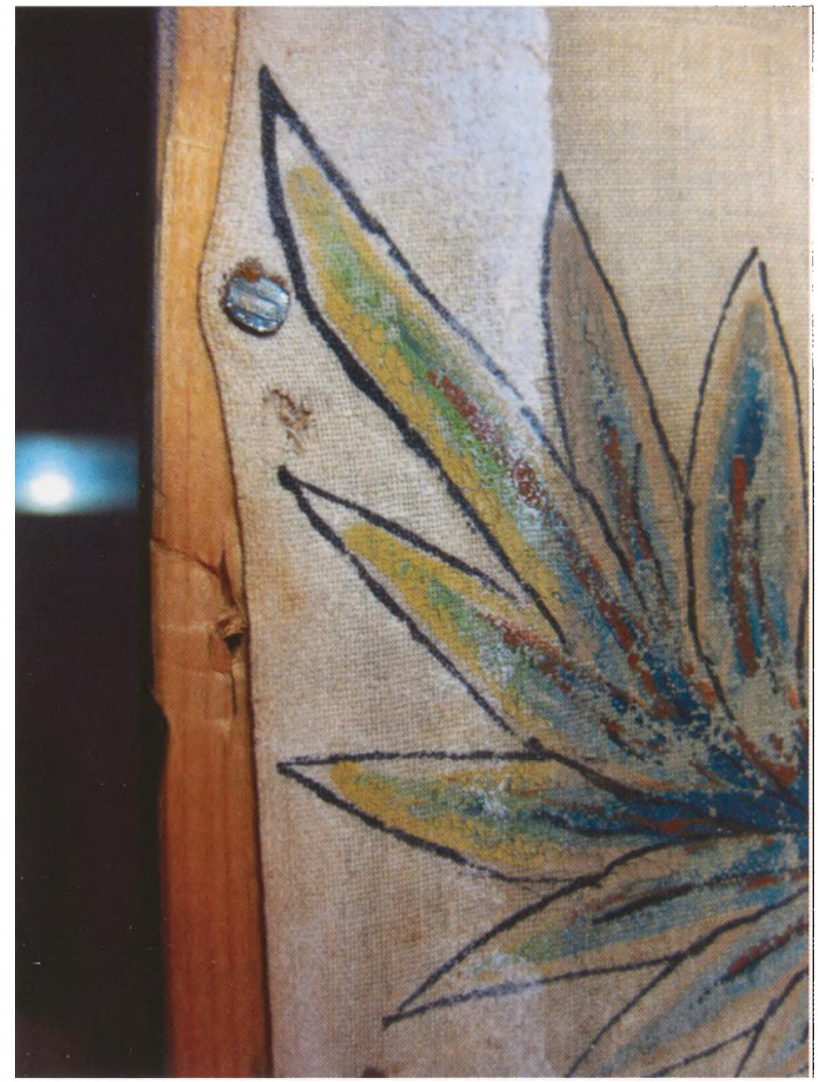

Vervolgens moesten de verf en het goud worden gevlakt en vastgezet, waarbij telkens werd nagegaan welke methode het meest geschikt was. Het grote doek bleek moeilijker te behandelen: na voorbehandeling moest de verf eerst aangedrukt worden voor het onder bezwaar (door middel van kleine zandzakjes) drogen. Na de lijm aangebracht te hebben werd het goud gevlakt met een verwarmde spatel. Tot slot is het goud met saliva afgeveegd, zodat het stralender werd.

Vooral de grote scheur in het Mahabaratha-doek vergde veel werk (afb. 2 en 3). Het doek was vervormd, de randen van de scheur raakten elkaar niet meer. Ze zijn naar elkaar toegebracht door de omgeving licht in te vochten, weer in vorm te brengen en onder bezwaar te drogen. Tenslotte zijn de beide zijden met Japans papier weer aan elkaar verbonden.

Beide doeken waren ingelijst als schilderij, wat duidt op een Westerse benadering. Nadat de deklatten verwijderd waren, kwamen de oorspronkelijke heldere kleuren te voorschijn (afb. 4). Die kleuren bieden uiteraard relevante historische informatie.

In eerste instantie bestond de intentie de doeken los van het frame te halen, zoals ze vroeger op Bali gebruikt waren. Dat zou echter nieuwe problemen geven voor de stabiliteit. De doeken zijn veel minder kwetsbaar en beter te hanteren als ze strak gespannen op het frame zitten, maar het zou jammer zijn de deklatten weer terug te plaatsen nu de nieuw ontdekte oude mooie kleuren weer zichtbaar zijn. Geëxposeerd zonder deklatten kan men zich meer indenken hoe ze er tijdens de crematie uitzagen. Brill. com@4/26/2023 11:49:12AM 
Hoewel het materiaal zal verouderen en wellicht degraderen en verpulveren, worden de doeken nu onder museale condities bewaard.

$\mathrm{Na}$ deze restauratie zijn de kleuren van de doeken helderder, stof en uitbloei zijn verwijderd. De verf zit weer vast evenals het goud, scheuren zijn gepatched, maar reversibel.

Restaureren is het rekken van het gevecht tegen de tijd. Door restauratie proberen we verleden, heden en toekomst met elkaar te verbinden en ons erfgoed te behouden. We hopen met de restauratie ook voor deze twee Balinese doeken een flinke voorsprong op de tijd te hebben gemaakt.

De gerestaureerde doeken zijn tot en met 17 oktober 2010 te zien in de tentoonstelling 'Doeken voor een dode vorst'.

- Museum Volkenkunde Steenstraat 1

2312 BS Leiden

di - zo van 10.00 tot 17.00 uur

www.museumvolkenkunde.nl

\section{Noten}

1. RMV 6090-1 en RMV 6090-2. Zie ook het artikel van F. Brinkgreve en R. GolderMiedema over de verzamelgeschiedenis en de iconografie van deze doeken in Aziatische Kunst 38/4 (2008), pp. 8-21.

2. De maatschap bestaat uit Bella Zurcher en Regien Geerke. Door hen is dit project uitgevoerd.

3. H.I.R. Hinzler, Schilderen en tekenen op Bali, 1978/1979, p. 26. 